International Journal of Pharmaceutics \& Pharmacology

\title{
Preliminary Phytochemical Screening of Extracts of Robinia pseudoacacia
}

\author{
Masood Ayoub Kaloo ${ }^{1,2}$, Bilal A Bhat ${ }^{1 *}$ and Gulzar Rafiqi ${ }^{1}$ \\ ${ }^{1}$ Department of Chemistry, Islamic University of Science and Technology, Awantipora Pulwama, Kashmir, India \\ ${ }^{2}$ Department of Chemistry, Govt. Degree College Shopian, Kashmir, India
}

\section{Article info}

Received 20 March 2018

Revised 30 April 2018

Published 07 May 2018

*Corresponding author: Bilal A Bhat, Department of Chemistry, Islamic University of Science and Technology, Awantipora Pulwama, Kashmir, India, E-mail: barbilal20@gmail.com

\begin{abstract}
The Robinia pseudoacacia (Fabaceae) is one of the medicinal plants, Native to North America, commonly distributed in various regions of Kashmir. The plant is used as an antispasmodium, febrifuge, antioxidant; diuretic, emollient, antitumor etc. The present study was carried out to screen different solvent extracts of the Robinia pseudoacacia phytochemically for the presence of active constituents like Alkaloids, Flavonoids Saponins, Tannins, and Phenols. However, the positive results for the detection of Flavonoids, Tannins and phenols were obtained. The maximum yield of ethyl acetate extract of plant leaves $38.23 \%$ was obtained.
\end{abstract}

Keywords: Robinia; Extract; Antioxidant; Diuretic; Antitumor; Alkaloids

\section{Introduction}

Robinia pseudoacacia (Fabaceae or Leguminosae), commonly known as black locust, is a medium sized, melliferous tree which grows upto 6 metres commonly distributed in sandy and rocky soils. Leaves are pinnately compound, bluish green on top, pale underneath. They have a pair of short thorns at the base. Leaflets are oval shaped. Bark is light grey and deeply furred. Flowers are small, pear shaped, formed in droppy clusture. Flowering period occurs in late spring, from May to June. It is a native plant in North America. In Kashmir, Robinia pseudoacacia frequently occurs in district Kupwara and banks of Mansbal Lake, Ganderbal [1].

The plant is used as an antispasmodic, febrifuge, antioxidant, diuretic, emollient, laxative, antitumor, and antimicrobial [2]. Dried leaves are helpful in treatment of wounds caused by wounds. It acts as pain reliever. Used internally, it calms stomach burns, and is usually recommended to individuals who suffer from hyperacid gastritis and distensions. It is helpful in easing digestion. It has a sedating and calming effect and could be very useful in cases of headaches and stress. Infusion added to baths can help young children who suffer from insomnia. Flower powder is used in cases of gastritis, duodenal and gastric ulcer. Four oligomeric flavonoids like Robinetinidol leucorobinetinidins, Robinetinidoldihydrorobinetins, Robinetinidol-robinetin and robinetinidol-flavone have been reported. Five flavonoids like Acacetin, Secundiflorol, Mucronulatol, Isomucronulatol and Isovestitol have been isolated from the ethanolic extract of the whole plant. A bioactivitydirected fractionation of the ethanolic extracts of Robinia pseudoacacia has yielded robinlin, a novel homomonoterpene. It has shown strong bioactivity in the brine shrimp lethality test (BST) [3]. All parts of the plant (except flowers) and especially the bark are considered to be toxic [4]. However, the toxins have been reported to get destroyed by heat. Literature survey revealed that Linalool, phenyl ethyl alcohol, methyl anthranilate, 1-hexanol and 3-methyl pyridine has been isolated from the oil of the flowers of Robinia pseudoacacia [5,6]. It also contains polyphenolic compounds in leaves such as tannins [7] and taxon specific monoterpene (Robinlin) [8]. In addition, some natural compounds with antibacterial activity have been 
identified in the leaves [9-11]. The compounds like Secundiflorol, Mucronulatol, Isomucronulatol and Isovestitol were identified by spectral analyses and were reported from this species in an ethanolic extract of leaves of the plant Robinia pseudoacacia [12]. The minor lectin was named as RpbA11 is a hometetramers compound was also isolated $[13,14]$.

\section{Results and Discussion}

\section{Extraction}

The powdered plant material was subjected to successive solvent extraction using solvents in increasing order of their polarity. Various solvents used were petroleum ether, ethyl acetate and methanol. The shade dried plant material subjected to sequential extraction in petroleum ether, ethyl acetate and methanol. Maximum yield was found in ethyl acetate extract (38.23\%). Total extractive values are tabulated in (Table 1, Figure 1).

Table 1: Extractive values of various extracts.

\begin{tabular}{|c|c|c|}
\hline S. No & Extracts & Extract values (\%) \\
\hline 1 & Petroleum ether & 6.45 \\
\hline 2 & Ethyl acetate & 38.23 \\
\hline 3 & Methanol & 13.69 \\
\hline
\end{tabular}

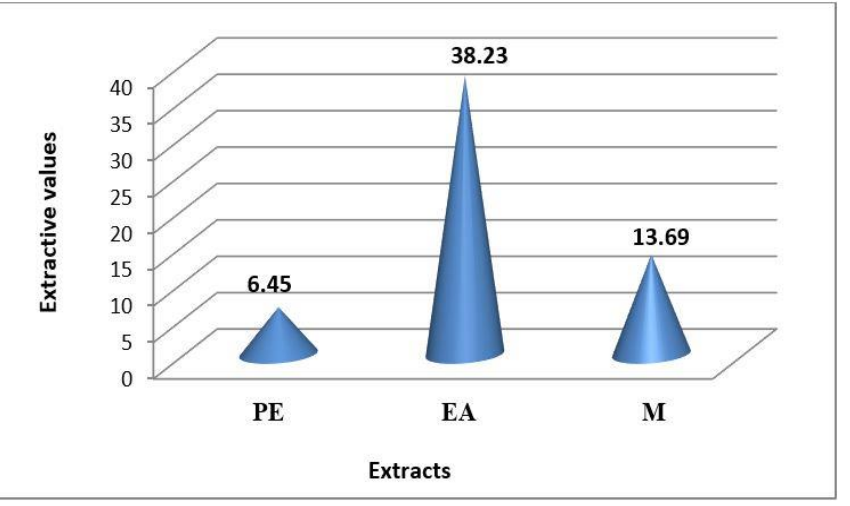

Figure 1: Relative extractive values of various extracts of Robinia pseudoacacia; [PE $\rightarrow$ Petroleum ether, $\mathrm{EA} \rightarrow$ Ethyl acetate, $\mathrm{M} \rightarrow$ Methanol].

\section{Petroleum ether extraction}

$60 \mathrm{~g}$ of the powdered material was extracted with petroleum ether (hot extraction) using soxhlet apparatus at boiling point temperature for 9-10 $\mathrm{h}$. The extraction was collected and dried in oven.
After defating the plant material of Robinia pseudoacacia with petroleum ether, the material was extracted with ethyl acetate (hot extraction) using soxhlet apparatus at boiling temperature for 15-20 h. The extract was carefully filtered using Whatmann's filter paper and concentrated in vacuum under reduced pressure using rotary evaporation and dried in oven at $40^{\circ} \mathrm{C}$.

\section{Methanol extraction}

Ethyl acetate extraction residue was dried completely and then extracted with methanol (hot extraction) using soxhlet apparatus at boiling temperature for about 48 hours. The extract was carefully filtered using a Whatmann's filter paper and finally concentrated in vacuum under reduced pressure using rotary evaporation. Concentrated extract was stored in labeled sterile bottle till further evaluation.

\section{Phytochemical Screening Procedure}

The different extracts so obtained were subjected to preliminary phytochemical screening. Phytochemical studies were performed to identify the presence of various phytoconstituents as follows:

\section{Alkaloids}

To the $2 \mathrm{ml}$ of methanolic filtrate, $1.5 \mathrm{ml}$ of $1 \% \mathrm{HCl}$ was added. After heating the solution in water bath, 6 drops of Mayer's reagent/Wagner's reagent/Dragendroff reagent was added. Formation of orange precipitate was observed to detect the presence of alkaloids [15].

\section{Flavonoids}

$2 \mathrm{~g}$ plant material was extracted in $10 \mathrm{ml}$ alcohol or water. To $2 \mathrm{ml}$ filtrate few drops of concentrated $\mathrm{HCl}$ followed by $0.5 \mathrm{~g}$ of zinc or magnesium turnings was added. The solution was observed for the appearance of magenta red or pink color after 3 minutes [16].

\section{Terpenes}

To $2 \mathrm{ml}$ of aqueous extract, $5 \mathrm{ml}$ chloroform, $2 \mathrm{ml}$ acetic anhydride and concentrated $\mathrm{H}_{2} \mathrm{SO}_{4}$ were added carefully to form layer. Reddish brown coloration of interface was observed to detect the presence of Terpenes [17]. 


\section{Tannins}

To $2 \mathrm{ml}$ of aqueous extract $2 \mathrm{ml}$ of $5 \% \mathrm{FeCl}_{3}$ was added and observed for the formation of yellow brown precipitate [16].

\section{Saponins}

Aqueous extract of $2 \mathrm{~g}$ powder was made the solution was shaken vigorously and observed for a stable persistent froth. The froth was mixed with few drops of olive oil and shaken vigorously after which it was observed for the formation of an emulsion [18].

\section{Steroids}

In a small quantity of petroleum ether extract, $2 \mathrm{ml}$ of acetic anhydride solution was added in $\mathrm{CHCl}_{3}$. This was followed by addition of conc. $\mathrm{H}_{2} \mathrm{SO}_{4}$. A green colour was produced which turns to blue indicates the presence of steroids.

\section{Phenols}

To $2 \mathrm{ml}$ of alcohol or aqueous extract, $1 \mathrm{ml}$ of $1 \%$ ferric chloride solution was added. Blue or green color indicated phenols [19].

\section{Glycosides}

A small quantity of the extract was dissolved in $1 \mathrm{ml}$ of water. Sodium hydroxide solution was added; yellow colour appeared that indicates the presence of glycosides.

\section{Anthraquinones}

$0.5 \mathrm{~g}$ of the extract was boiled $10 \mathrm{ml}$ of sulphuric acid $\left(\mathrm{H}_{2} \mathrm{SO}_{4}\right)$ and filtered while hot. The filtrate was shaken with $5 \mathrm{ml}$ of chloroform $\left(\mathrm{CHCl}_{3}\right)$. The chloroform layers was pipette into another test tube and $1 \mathrm{ml}$ of dilute ammonia was added. The resulting solution was observed for colour change [17].

\section{Phytochemicals analyses of various extracts}

Preliminary phytochemical analysis of various extracts showed the presence of certain phytochemicals (constituents) in the extracts. The tests were performed using above standard procedures. The qualitative analysis of successive extracts of leaves of Robinia pseudoacacia has revealed the presence of Terpenoids, Flavonoids, Glycosides, Phenols, Tannins, and Steroids. However, Alkaloids, Saponins, Proteins, Anthraquinones were found to be absent (Table 2).
Table 2: Phytochemical screening of various extracts.

\begin{tabular}{|c|c|c|}
\hline S. No & Constituents & Observation \\
\hline 1 & Alkaloids & Absent \\
\hline 2 & Anthraquinones & Absent \\
\hline 3 & Flavonoids & Present \\
\hline 4 & Glycosids & Present \\
\hline 5 & Phenols & Present \\
\hline 6 & Proteins & Absent \\
\hline 7 & Saponins & Absent \\
\hline 8 & Steroids & Present \\
\hline 9 & Tannins & Present \\
\hline 10 & Terpenoids & Present \\
\hline
\end{tabular}

\section{Conclusion}

In summary, different extracts of leaves of Robinia pseudoacacia have been obtained. These extracts were phytochemically screened for different active chemical constituents like Terpenoids, alkaloids, tannins, steroids, saponins, proteins, flavonoids and glycosids. The presence of terpenoids, steroids, glycosids and flavonoids in the extracts of leaves of Robinia pseudoacacia may become a field of research for their isolation and exploration in future.

\section{Acknowledgement}

The authors have no acknowledgements to report.

\section{Conflict of Interest}

The authors have no actual or potential conflicts of interest to report.

\section{Funding}

No support in the form of grants, equipment, and/or drugs were received in the conduct of this research.

\section{References}

1. Wani NR, Mugha AH. Studies on vegetation analysis of the afforestated Mansbal Lake, Kashmir-India. J Horticult Forestry Biotechnol 2012; 16: 35-38.

2. Rosu AF, Bita A, Calina D, et al. Synergic antifungal and antibacterial activity of alcoholic extract of the species Robinia pseudoacacia L. Eur J Hosp Pharm 2012; 19: 216.

3. Tian F, Chang CJ, Grutzner JB, et al. A noval bioactive homo-monoterpene from Robinia pseudoacacia L. (Fabaceae). Bioorg Med Chem Letters 2001; 11: 2603-2606. 
4. Cooper M, Johnson A. Poisonous plants in Britain and their effects on animals and Man. HMSO ISBN 1984.

5. Jia CX, Xiong WD, Mao DB, et al. Analysis of organic acids in Hovenia dulcis Thunb peduncle by GC-MS. J Chinese Inst Food Sci Technol. 2005; 1: $72-74$.

6. Li ZL, Xue DY, Zhang JQ et al. Study on Robinia pseudoacacia. J Lanzhou (China) Univ (Nat Sci Edn) 1993: 29; 124-126.

7. Long CZ, Xin KM, Wang LY et al. Isolation of flavonoids from flowers of Robinia pseudoacacia. Nat Prod Res Devl 1991; 3: 84-87.

8. Rakesh DD, Bhat TK, Singh B. Isolation of constituents of leaves of Robinia pseudoacacia. J Gen Appl Microbiol 2000; 46: 99.

9. Tian F, Chang CJ, Grutzner J, et al. Constituents from roots of Robinia pseudoacacia. Bioorg Med Chem Lett 2001; 11: 2603.

10. Kupchik EJ, Pisano MA, Carroll AM, et al. Antimicrobial activity of $\mathrm{N}$-substituted N(triphenylstannyl) cyanamides and triethylammonium (organocyanoamino) chlorotriphenylstannates. J Pharm Sci 1980; 69: 340.

11. Kamo T, Takemura T, Wasano N, et al. Flavonoids of Robinia pseudoacacia. Biosci Biotechnol Biochem 2012; 76: 1416.
12. Tian F, McLaughlin JL. Chemical constituents of Robinia pseudoacacia. Pharm Biol 2000; 38: 229.

13. Sharon N, Lis H. Legume lectin: A large family of homologous proteins. FASEB J 1990; 4: 31983208.

14. Horejsi V, Haskovec C, Kocourek K. Studies on lectins: Isolation and characterization of the lectin from black locust bark (Robinia pseudoacacia L.). Nature 1978; 227: 680-685.

15. Oguyemi, AO in: Sofowora A. ed., Proceedings of a Conference on African Medicinal Plants. Ife-Ife: Univ Ife 1979; 20-22.

16. Parekh J, Chanda S. Antibacterial and phytochemical studies on twelve species of Indian medicinal plants. Afr $\mathrm{J}$ Biomed Res 2007; 10 .

17. Harborne JB. Phytochemical Methods: A Guide to Modern Techniques of Plant Analysis, Chapman and Hall, London, UK, 1973.

18. Sofowora A. Medicinal Plants and Traditional Medicine in Africa. Spectrum Books Ltd., Ibadan, Nigeria, 1993; pp. 191-289.

19. Martinez A, Valencia G. Manual de practicas de Farmacognosia y Fitoquimia: 1. Universidad de Antiquia, Medellin, 2003; 59-65.

This manuscript was peer-reviewed

Mode of Review: Single-blinded

Academic Editor: Kamran Ahmad

Copyright: (92018 Kaloo MA, et al. This article is distributed under the terms of the Creative Commons Attribution 4.0 International License (http://creativecommons.org/licenses/by/4.0/), which permits unrestricted use, distribution, and reproduction in any medium, provided you give appropriate credit to the original author(s) and the source, provide a link to the Creative Commons license, and indicate if changes were made. 